\title{
Comparison Study Between Family Business Franchisee and Non-Family Business Franchisee
}

\author{
Nurul Ashykin Abd Aziz ${ }^{1,2^{*}} \&$ Mohd Hizam Hanafiah ${ }^{1}$ \\ ${ }^{1}$ Faculty of Economics and Management, Universiti Kebangsaan Malaysia, Malaysia \\ ${ }^{2}$ Faculty of Entrepreneurship and Business, Universiti Malaysia Kelantan, Malaysia \\ Email:ashykin.a@umk.edu.my \\ DOI: https://doi.org/10.37134/jcit.vol10.2.2020
}

Cite this paper (APA): Abd Aziz, N. A., \& Hanafiah, M. H. (2020). Comparison Study Between Family Business Franchisee and Non-Family Business Franchisee. Journal of Contemporary Issues and Thought, 10, 17-26. https://doi.org/10.37134/jcit.vol10.2.2020

\begin{abstract}
This research is examining the entrepreneur's involvement in family business franchisee and non-family business franchisee. In addition, this study discussed about the differences of these both of business based on factors such as intrinsic reward, perceived autonomy and family. The factors are developed from goal setting theory and agency theory are used as the basis for studying franchising. The quantitative methodology is adopted for this study and the result shows that perceived economy is not significant meanwhile the intrinsic reward and family is significant.
\end{abstract}

Keywords: Family Business; Franchising; Family Firms

\section{Introduction}

Nowadays, franchising became a strategy adopted by many firms to expand their family business (Rosado-Serrano, 2017). By definition, franchising is a form of system where the franchisor as a parent company grants the franchisee and give the right to run a business in a given system (Combs et al., 2004; Czinkota et al., 2004). Furthermore, Czinkota and Ronkainen (2010) supported that franchising is an entrepreneurial strategy that works as a market entry form for firms to expand their business internationally. In discussing about family business, Donnelley (1988) described that family business is where two generations of the family link had a mutual influence on company policy, interest and objectives.

According to Rosado-Serrano (2017), family firms are different in their organizational structures where some are wholly owned by the operating family and others may have two groups of family or public firms controlled by family. Even though these firms are independent organizational forms, they need to contribute to profit and growth distribution. Besides that, the family firm is a governance structure that allows for such actions and firm considered as a family business in order to extent its ownership and management within a family unit; thus it maintains intraorganizational family-based relatedness and social capital (Arregle et al., 2007; Sirmon \& Hitt, 2003). Likewise, family firms considered as a commitment-intensive organization where family 
members have a strong attachment to the business as well as to family relationships (Chirico, 2008; Gómez-Mejía et al., 2007; Zellweger, 2007).

On the other hand, Habbershon et al. (2003) claimed that family firms are dynamic, unusually complex and rich in intangible resources. In detail, intangible resources of family business are identified through a resource-based view where it represented as a competitive advantage in family firms but not available in non-family firms (i.e. Cabrera-Suárez et al., 2001; Chirico et al., 2011; Pearson et al., 2008). Furthermore, family business defines the typical bundle of resources gather from the family interaction, its individual members and the business itself to sustain the firm across generations. Indeed, the collaborating and relationship of both family and firm provides the family business with an intangible resource base where non-family family businesses cannot duplicate (Habbershon et al., 2003; Pearson et al., 2008).

Moreover, family firms are the backbone of the economy and development of many countries in the world. In addition, these family firms played an important role in developed the entrepreneurial class in Latin America, thus reaching the international markets (Rosado-Serrano, 2017). From the context of the family business, franchising has been underserved in the franchising literature and family business literature (Baena, 2011). Franchising can be an entrepreneurial strategy for market entry form for firms to go globally and this goes in hand with family firms where the engagement and life expectancy has a long term view (Czinkota et al., 2010; Rosado-Serrano, 2017). The nature of family business is characterized by some factors to survive (Arregle et al., 2007; Chirico, 2008). In the context of franchising, this type of business is a form of inter-firm cooperation between two organizations where both are entrepreneurs who shared tangible and intangible resources with the goal of increasing their business performance (Combs \& Ketchen, 1999). As claimed by Tuunanen and Hyrsky (2001), the family business was one of the most related advantages for franchisees. Fundamentally, entrepreneurs' goals are focused, and they commence entrepreneurial activities for several monetary and non-monetary goals such as independence, profit, recognition, personal growth, family support, approval and flexible lifestyle (Hizam-Hanafiah, 2012; Tuunanen \& Hyrsky, 2001).

Academics have debated family business franchisee versus non-family business franchisee (e.g Chirico et al., 2011; Sirmon \& Hitt, 2003; Zellweger, 2007). Although questioned, franchising is often considered as lower rates of business failure than other types of business organization (Cavaliere \& Swerdlow, 1988; Price, 1996). In this article, researchers theorize about the differences between family business franchisee and non-family business franchisee based on the factors such as intrinsic reward, perceived economy and family. According to past literature, study on family business franchisee was still vague and need to be explored (Chirico et al., 2011; Rosado-Serrano, 2017). By increasing the understanding on factors of family business engagement will resulting more satisfaction in franchising relationships compare to non-family business franchisee, thus enhance the intention to remain in that business (Chirico et al., 2011). Besides, Rosado-Serrano (2017) highlighted that empirical studies of family firms who are using franchising need to test by the model. Thus, the present study explored the nature of family business firm and non-family business franchising by making a comparison based on the factors of intrinsic reward, perceived economy and family.

\section{Literature Review}




\section{Agency Theory}

Even though franchisors value the benefits of the mix of ownership forms and do sustain that mover time, there is the support of a greater tendency to eternally convert existing franchised outlets to company-owned outlets in gaining greater access to resources as claimed by (Dant et al., 2011). On the other hand, Rubin (1978) criticizing that there is another important element in franchising to survive which is human capital thus he proposed Agency Theory. In addition, Agency theory highlighted that the franchisor (principal) is depending to the franchisee (agent) in performing some action behalf on the franchisor. In contrast with the Resource Scarcity Theory, Brickley et al. (1991) proposed the argument that the franchising system is an effective business model in controlling the principal-agent problem. In addition, this theory highlighted that there is a difference in interest between both parties (franchisor-franchisee) where company-owned outlets will pursue their goals, thus create a conflict of interest.

Moreover, the issues are whether the agent (franchisees) is contributing the effort in aligning with the principal (franchisor) goals and either behaving in the interest of principal or in own interest. Logically, Agency Theory emphasizes that franchise system is a powerful motivator where franchisor will convert their company-owned properties to franchise in order to gain competitive advantage by reducing the agency cost. Franchising is a prominent platform for company to organize their distribution sector. Scholars develop a model to show that partial monitoring where franchisor only monitors only a subset of its company/outlet (Cliquet \& Pénard 2012). In addition, Ishak et al. (2016) claimed that franchising enables rapid expansion using franchisee resources such as financial capital and managerial talent as key in forming and supporting the standing market knowledge.

\section{Goal Setting Theory}

According to Locke (1996), goal setting theory is developed within the work based on a premise where much human action is purposeful and directed by conscious goals. Furthermore, entrepreneur motivation to continue the business depends on the set of goals achievement during the entrepreneurial process as claimed by Bawn et al., (2001). Besides that, Porter et al., (2003) supported that goals perform as a motivational function by doing four things. First and foremost, a goal is an exercise selective observation as it directly to one's attention to a specific target. For this, the likelihood of pursuing a given goal is increased as the franchisee thinks that it can be accomplished. Klein (1991) claimed that franchisee commitment towards a goal is important as commitment will be heightened when franchisee believes that the importance and possibility to achieve that goal. Secondly, to achieve a goal, it requires a sustained effort and persistence where franchisee needs a sustainable effort and energy to realize that goal. Thirdly, a goal will encourage one to employ an effort in achieving something specific where goals will direct the activity of franchisees toward their actions either relevant to not. Thus, franchisee begins to run its business with high support and assistance from the franchisor to achieve mutual goals. Finally, since goal creates the issues of linking the gap between actual and desired, it will foster the strategy and action plans as mentioned by Kreitner (2001). 
According to Iyengar and Lepper (1999), intrinsic rewards defined as internal experienced and self-granted. Furthermore, Schaper et al. (2007) claimed that many entrepreneurs are sustained and motivated through other means that money. In addition, entrepreneurs set their goals to be one's own boss, having control over one's destiny and be responsible for the success of the venture. Besides that, satisfying the need for achievement is also the component of intrinsic rewards (Johnson 1990; Moore et al., 2010). Past studies revealed that intrinsic reward is one of the important goals required by the entrepreneur and is deemed to be the second most important goal for them (Berthold \& Neumann 2008; Wang et al., 2006). Moreover, Naylor (2003) explained that intrinsic reward is resulting from the process of performing a function. Entrepreneurs are the satisfactions person who receives in the process of performing an action or personal satisfying outcomes (Daft, 2012).

Benzing et al. (2005) highlighted that the main reason for becoming an entrepreneur is the need for autonomy. Furthermore, the autonomy is related with the target to seek for personal rewards (Boyd \& Gumpert, 1983), independence from others (Hellriegel et al., 2004), freedom by being one's own boss (Knight, 1984), controlling one's own future and satisfying the need for achievement (Bird, 1988). On the other hand, perceived autonomy is also related with controlling own employment destiny, working at the preferable place and having flexibility in their lifetime. Past study revealed that many countries showed that franchisees also seek for an autonomy as their main motivation to become as a franchisee, thus franchising has been perceived as the benefits of autonomy (Kaufmann, 1999). Moreover, franchisees pursue autonomy in running a business (Kidwell et al., 2007; Paik \& Choi, 2007).

On the other hand, family factors also identified as important to entrepreneurs (Benzing \& Chu, 2009; Kuratko et al., 1997; Robichaud et al., 2001). According to Lahra (2005), family becomes a more important factor in business as family ownership and involvement promote entrepreneurship. Furthermore, Aldrich and Cliff (2003) described that the incorporation of family in business has consequences on the development of new business opportunities, startup decision and resource deployment process. A past study by Lee (2006) found that family adaptability within a business is significant with organizational commitment, life satisfaction and work satisfaction. In addition, Lee (2006) highlighted that family relationship has a significant influence on the attitudes and behaviours of the second generation working in family business.

According to Lee (2006), relationships of family have a significant influence on the bahaviours and attitudes of the second generation working in family business. Furthermore, some scholars emphasized that family factors can offer for job security and most of entrepreneurs enjoy continuing their family business as a tradition (Benzing et al, 2005; Berthold \& Neumann, 2008). Nevertheless, Gray et al. (2006) highlighted that that the family factor is important in defining entrepreneurs' involvement in business and past study by Shinnar and Young (2008) found 44.6 percent of entrepreneurs wanted to involve family members. Welsh and Raven (2011) described that family firms actively engaged with franchising. Besides that, Kaufmann and Stanworth (1995) explained that franchising allow individuals to create a jobs and sources of long-term wealth for the family members. Through entrepreneurship, franchisees can provide a job for their family members and thus balance their life and family. As discussed by these scholars, economic gain is financial and economic gain by franchisee based on their participation and involvement in the franchise business (Daft, 2012; Hellriegel, 2004). Based on that discussion, as franchisees achieved 
their goals interrelated with family business, they would struggle to maintain their attempt as a franchisee. Thus, in aligning with the discussion above, the following propositions are suggested:

P1: Family Business franchisee has higher goal attainment of Perceived Autonomy than nonfamily Business franchisee

P2: Family Business franchisee has higher goal attainment of Economic Gain than non-family Business franchisee

P3: Family Business franchisee has higher goal attainment of Intrinsic Reward than non-family Business franchisee

P4: Family Business franchisee has higher goal attainment of Family Concern than non-family Business franchisee

\section{Research Methodology}

This study highlighted the factors influencing the goal attainment and comparison between family business franchisee and non-family business franchise in Malaysia. Therefore, a quantitative methodology was adopted for the present study. The samples are withdrawn from family business franchisee from various sectors in Malaysia such as food business, service and maintenance, learning center and nursery, clothing and accessories, health and beauty care, IT and electronics, convenience shop and supermarket and other businesses. To collect the data for this study, a convenience sampling technique was used. According to Hair et al. (2011), convenience sampling involves selecting sample elements that are most readily available to participate in the present study and can provide the information requires. In addition, convenience samples are used because it is enabling the researcher to complete many interviews quickly and cost effectively.

Besides that, this study also utilized questionnaires as a survey to the targeted respondents. Sekaran and Bougie (2010) described that survey is an activity where respondents answer the questions administered through questionnaires or interview sessions by the researcher. In overall, the number of respondents who participated in this study was 204 franchisees. This data was analyzed using Statistical Packages for the Social Sciences (SPSS) version 22.

\section{Finding and Discussion}

Demographic Profiles of Respondent 
Table 1: Demographic Profiles Analysis

\begin{tabular}{|c|c|c|c|c|c|}
\hline \multirow[t]{2}{*}{ Characteristics } & \multicolumn{4}{|c|}{ Category } & \multirow[t]{2}{*}{ Number (\%) } \\
\hline & \multicolumn{2}{|c|}{$\begin{array}{l}\text { Family Business } \\
\text { Franchisee }\end{array}$} & \multicolumn{2}{|c|}{$\begin{array}{l}\text { Non-family Business } \\
\text { Franchisee }\end{array}$} & \\
\hline \multirow[t]{3}{*}{ Gender } & \multicolumn{2}{|c|}{45 (Male) } & \multicolumn{2}{|c|}{66 (Male) } & $111(54.4 \%)$ \\
\hline & \multicolumn{2}{|c|}{ 45(Female) } & \multicolumn{2}{|c|}{48 (Female) } & $93(45.6 \%)$ \\
\hline & Mean & $\begin{array}{c}\text { Std. } \\
\text { Deviation }\end{array}$ & Mean & $\begin{array}{c}\text { Std. } \\
\text { Deviation }\end{array}$ & - \\
\hline Level of Education & 5.74 & 1.395 & 5.83 & 1.363 & - \\
\hline $\begin{array}{c}\text { Financial } \\
\text { Dependency }\end{array}$ & 5.41 & 1.348 & 5.44 & 0.978 & - \\
\hline Business Experience & 2.42 & 0.874 & 2.47 & 0.914 & - \\
\hline $\begin{array}{l}\text { Management } \\
\text { Experience }\end{array}$ & 2.622 & 0.8424 & 2.693 & 0.8322 & - \\
\hline
\end{tabular}

For the present study, the analysis shows that the number of entrepreneurs from family business franchisee was 90 (male $=45$ and female $=45)$ compared to non-family business franchisee which was 114 (male $=66$ and female $=48)$. Thus, it indicated that majority of entrepreneurs are involved in non-family business franchise. According to Table 1, it shows the analysis on the level of education. For this study, it can be summarized that the mean of entrepreneurs with education is high in non-family business franchisee $($ mean $=5.83$, standard deviation $=1.363$ ) compared to family business franchisee (mean $=5.74$, standard deviation $=1.395$ ). In term of financial dependency, the result shows that non-family business franchisee (mean $=5.44$, standard deviation $=0.978$ ) relied on financial assistance compared to family business franchisee (mean $=$ 5.41, standard deviation $=1.348$ ). Next, Table 1 also shows about an analysis of business experience factor where it indicated that majority number of entrepreneurs in non-family business franchisee $($ mean $=2.47$, standard deviation $=0.914$ ) are agreed that business experience is important compared to family business franchisee (mean $=2.42$, standard deviation $=0.874$ ). Lastly, management experience has also been considered where the result indicated that entrepreneurs from non-family business franchisee (mean $=2.693$, standard deviation $=0.8322$ ) had a management experience compared to family business franchisee (mean $=2.622$, standard deviation $=0.8424$ ) .

Proposition Test

Table 2: Results of Analysis 


\begin{tabular}{cccccccc}
\hline Factors & $\begin{array}{c}\text { Family } \\
\text { Business } \\
\text { Franchisee }\end{array}$ & $\begin{array}{c}\text { Non-family } \\
\text { Business } \\
\text { Franchisee }\end{array}$ & $\begin{array}{c}\text { Family } \\
\text { Business } \\
\text { Franchisee }\end{array}$ & $\begin{array}{c}\text { Non-family } \\
\text { Business } \\
\text { Franchisee }\end{array}$ & F & t & $\begin{array}{c}\text { Sig (2- } \\
\text { tailed) }\end{array}$ \\
\cline { 2 - 6 } Mean & \multicolumn{2}{c}{ Standard Deviation } & & & \\
\hline $\begin{array}{c}\text { Perceived } \\
\text { Autonomy } \\
\text { Economic } \\
\text { Gain }\end{array}$ & 5.6519 & 5.4046 & 0.95369 & 0.97611 & 0.135 & 1.815 & 0.071 \\
$\begin{array}{c}\text { Intrinsic } \\
\text { Reward } \\
\text { Family }\end{array}$ & 5.3074 & 5.1404 & 1.16383 & 1.08412 & 0.006 & 1.058 & 0.291 \\
Concern & 5.5444 & 5.5865 & 0.71163 & 0.93637 & 4.869 & 2.472 & 0.014 \\
\hline
\end{tabular}

Table above shows the results for the following propositions and discuss as follow:

P1: Family Business franchisee has higher goal attainment of Perceived Autonomy than non-family Business franchisee

According to Table 2, the mean of perceived autonomy for family business franchisee was 5.65 $(S D=0.95)$ and the mean for non-family business franchisee was $5.40(S D=0.98)$. Mean for the family business franchisee was greater than the mean for non-family business franchisee, we can conclude that family business franchisee was significantly than non-family business franchisee. According to $t$-test, value of $t$ was $(202)=1.815, p>0$. 05. Additionally, the $p$-value of Perceived Autonomy is 0.071 and this value is greater than 0.05 . For this, we can conclude that there is no statistically significant difference between family business franchisee and non-family business franchisee. Even though the perceived autonomy was not significant at $95 \%$ confidence interval of the difference, significance value at $90 \%$ can be accepted and we found the confidence interval for perceived autonomy are on scale -0.02134 to 0.51599 at $90 \%$ confidence interval of the difference, thus we accept the P1.

P2: Family Business franchisee has higher goal attainment of Economic Gain than non-family Business franchisee

The mean of perceived autonomy for economic gain for family business franchisee was 5.31 (SD $=1.16$ ) and the mean for non-family business franchisee was 5.14 (SD =1.08). Mean for the family business franchisee was greater than the mean for non-family business franchisee, we can conclude that family business franchisee was significantly than non-family business franchisee. According to t-test, we reject the P2 because there was not enough evidence to suggest a significance difference between the economic gain of these two types of business (i.e. family business franchisee and non-family business franchisee), $t(202)=1.058, p>0$. 05. Additionally, the p-value of economic gain is 0.291 and this value was greater than 0.05 . For this, we can conclude that there is no statistically significant difference between family business franchisee and non-family business franchisee. Thus, we reject the P2. 
P3: Family Business franchisee has a higher goal attainment of Intrinsic Reward than non-family Business franchisee

Refer to Table 2, the mean of intrinsic reward for the family business franchisee was 5.88 (SD = $0.711)$ and the mean for non-family business franchisee was $5.59(\mathrm{SD}=0.94)$. Mean for the family business franchisee was greater than the mean for non-family business franchisee, we can conclude that family business franchisee was significantly than non-family business franchisee. According to $\mathrm{t}$-test, value of $\mathrm{t}$ was $(202)=2.472, \mathrm{p}>0$. 05. Additionally, the $\mathrm{p}$-value of intrinsic reward was 0.014 and this value was less than 0.05 . For this, we can conclude that there is a statistically significant difference between family business franchisee and non-family business franchisee. Thus, we accept the P3.

P4: Family Business franchisee has higher goal attainment of Family Concern than non-family Business franchisee

According to Table 2, the mean of family concern for family business franchisee was 5.54 (SD = 1.07 ) and the mean for non-family business franchisee was 5.21 ( $\mathrm{SD}=1.17$ ). Mean for the family business franchisee was greater than the mean for non-family business franchisee, we can conclude that family business franchisee was significantly than non-family business franchisee. According to $t$-test, value of $t$ was $(202)=2.161, p>0$. 05. Additionally, the $p$-value of intrinsic reward was 0.032 and this value was less than 0.05 . For this, we can conclude that there is a statistically significant difference between family business franchisee and non-family business franchisee. Thus, we accept the P4.

\section{Conclusion and Limitations}

The significance of perceived autonomy, intrinsic reward and family concern has been acknowledged by past literature. The results for the present study highlighted economic gain has not been found to have a relationship with the entrepreneur's performance in involving family business franchisee or non-family business franchisee. Perhaps, the economic gain has not inspired them as goal attainment. Besides that, the factors of perceived autonomy, intrinsic reward and family concern are positively significant with these both of business types (i.e. family business franchisee and non-family business franchisee). As an overall, this study has a limitation. Due to the cross-sectional study design, this present study was not capable to investigate the variations of other variables over the period. Future research may employ a qualitative study to explore further other factors that might influence the performance of both family business franchisee and non-family business franchisee.

\section{References}


Aldrich, H.E. (1990). Using an ecological perspective to study organizational founding rates. Entrepreneurship Theory and Practice, 14(3), 7-24.

Arregle, J.L., Hitt, M.A., Sirmon, D.G., \& Very, P. (2007). The development of organizational social capital: Attributes of family firms. Journal of management studies, 44(1), 73-95.

Baena, V. (2011). The effect of corruption on global franchising in emerging markets. International Journal of Business and Emerging Markets, 3(1), 57.

Bawn, J.R., Locke, E.A., \& Smith, K.O. (2001). A multidimensional model of venture growth. Academy of Management Journal, 44(2), 292-303.

Benzing, C., Chu, H.M., \& Kara, O. (2009). Entrepreneurs in Turkey: A factor analysis of motivations, success factors, and problems. Journal of Small Business Management, 47(1), 58-91.

Benzing, C., Chu, H.M., \& Callanan, G. (2005). Regional comparison of the motivation and problems of vietnamese entrepreneurs. Journal of Developmental Entrepreneurship, 10(1), 3-27.

Berthold, N., \& Neumann, M. (2008). The motivation of entrepreneurs: are employed managers and self-employed owners different? Intereconomics, 43(4), 236-244.

Bird, B. (1988). Implementing entrepreneurial ideas: The case for intention. Academy of management Review, 13(3), 442-453.

Boyd, D.P., \& Gumpert, D.E. (1983). Coping with entrepreneurial stress. Harvard business review, 61(2), 44.

Brickley, J.A., Dark, F.H., \& Weisbach, M.S. (1991). An agency perspective on franchising. Financial Management, 20(1), 27-35.

Cabrera-Suárez, K., De Saá-Pérez, P., \& García-Almeida, D. (2001). The succession process from a resource- and knowledge-based view of the family firm. Family Business Review, 14(1), 37-46.

Cavaliere, F.J., \& Swerdlow, M.R. (1988). Why Franchise? Business Forum, 13(3), 11-13.

Chirico, F. (2008). Knowledge accumulation in family firms. Evidence from four case studies. International Small Business Journal, 26(4), 433-462.

Chirico, F., Ireland, R.D., \& Sirmon, D.G. (2011). Franchising and the Family Firm: Creating Unique Sources of Advantage Through "Familiness". Entrepreneurship Theory and Practice, 35(3), 483-501.

Cliquet, G., \& Pénard, T. (2012). Plural form franchise networks: A test of Bradach's model. Journal of Retailing and Consumer Services, 19(1), 159-167

Combs, J.G., \& Ketchen, D.J. (1999). Can capital scarcity help agency theory explain franchising? Revisiting the capital scarcity hypothesis. The Academy of Management Journal, 42(2), 196-207.

Combs, J.G., Michael, S.C., \& Castrogiovanni, G.J. (2004). Franchising: A review and avenues to greater theoretical diversity. Journal of Management, 30(6), 907-931.

Czinkota, M.R., \& Ronkainen, I.A. (2010). International Marketing. (10th ed.). Mason: South Western Cengage Learning.

Czinkota, M.R., Ronkainen, I.A., \& Donath, B. (2004). Mastering global markets: strategies for today's trade globalist. Mason: Thomson South Western.

Daft, R. L. (2012). New Era of Management. Tenth edition. Singapore: Cengage Learning.

Dant, R.P., Grünhagen, M., \& Windsperger, J. (2011). Franchising research frontiers for the twenty-first century. Journal of Retailing, 87(3), 253-268.

Donnelley, R.G. (1988). The family business. Family Business Review, 1(4), 427-445.

Gómez-Mejía, L.R., Haynes, K.T., Núñez-Nickel, M., Jacobson, K.J., \& Moyano-Fuentes, J. (2007). Socioemotional wealth and business risks in family-controlled firms: Evidence from Spanish olive oil mills. Administrative science quarterly, 52(1), 106-137.

Gray, K.R., Foster, H., \& Howard, M. (2006). Motivations of Moroccans to be entrepreneurs. Journal of Developmental Entrepreneurship, 11(04), 297-318.

Habbershon, T.G., Williams, M., \& Macmillan, I.C. (2003). A unified systems perspective of family firm performance. Journal of Business Venturing, 18(4), 451-465.

Hair, J.F., Money, A.H., Samouel, P., \& Page, M. (2011). Essentials of business research methods. (2nd ed.). United States of America: M.E SHarpe.Inc.

Hellriegel, D., Jackson, S.E., \& Slocum, J.W. (2004). Management. Ohio: South Western.

Hizam-Hanafiah, M. (2012). The relationship between goal attainment and intention to remain in a franchise system in Malaysia. University of Essex: Unpublished $\mathrm{PhD}$ thesis.

Ishak, K.A., Wei, F.C.C., \& Romle, A.R. (2016). The roles of trust in franchising relationship: the Malaysian franchisees' perspectives. Middle-East Journal of Scientific Research, 24(6), 2071-2078.

Iyengar, S.S., \& Lepper, M.R. (1999). Rethinking the value of choice: A cultural perspective on intrinsic motivation. Journal of personality and social psychology, 76(3), 349-366. 
Johnson, B.R. (1990). Toward a multidimensional model of entrepreneurship: the case of achievement motivation and the entrepreneur. Entrepreneurship Theory and Practice, 14(3), 39-54.

Kaufmann, P.J. (1999). Franchising and the choice of self-employment. Journal of Business Venturing, 14(4), 345362.

Kaufmann, P.J., \& Stanworth, J. (1995). The decision to purchase a franchise: A study of prospective franchisees. Journal of Small Business Management, 33(4), 22-32.

Kidwell, R.E., Nygaard, A. \& Silkoset, R. (2007). Antecedents and effects of free riding in the franchisor - franchisee relationship. Journal of Business Venturing, 22(4), 522-544.

Klein, H.J. (1991). Further evidence on the relationship between goal setting and expectancy theories. Organizational Behaviour and Human Decision Processes, 49(2), 230-257.

Knight, R.M. (1984). The independence of the franchise entrepreneur. Journal of Small Business Management, 22(2), 53-61.

Kreitner, R. (2001). Management. (8th ed). Boston: Houghton Mifflin Company.

Kuratko, D.F., Hornsby, J.S., \& Naffziger, D.W. (1997). An examination of owner's goals in sustaining entrepreneurship. Journal of small business management, 35(1), 24.

Lee, J. (2006). Family Firm Performance: Further Evidence. Family Business Review, 19(2), 103-114.

Locke, E. A. (1996). Motivation through conscious goal setting. Applied and preventive psychology, 5(2), 117-124.

Moore, C.W., Petty, J.W., Palich, L.E., \& Longenecker, J.G. (2010). Managing Small Business: An Entrepreneurial Emphasis. (15th ed.). Singapore: South-Western.

Naylor, J. (2003). Management. Essex: Pearson Education Limited.

Paik, Y., \& Choi, D.Y. (2007). Control, autonomy and collaboration in the fast food industry: a comparative study between domestic and international franchising. International Small Business Journal, 25(5): 539-562.

Pearson, A.W., Carr, J.C., \& Shaw, J.C. (2008). Toward a theory of familiness: A social capital perspective. Entrepreneurship Theory and Practice, 32(6), 949-969.

Porter, L.W., Bigley, G.A., \& Steers, R.M. (2003). Motivation and Work Behaviour. (7th ed.). New York: Mc-Graw Hill.

Price, S. (1996). Behind the veneer of success: Propensities for UK franchisor failure. London: Small Business Research Trust Report.

Robichaud, Y., McGraw, E., \& Alain, R. (2001). Toward the development of a measuring instrument for entrepreneurial motivation. Journal of Developmental Entrepreneurship, 6(2), 189.

Rosado-Serrano, A. (2017). Franchising as strategy for internationalization of family firms: An exploratory study. Neumann Business Review, 3(1), 145-165.

Rubin, P.H. (1978). The Theory of the Firm and the Structure of the Franchise Contract. The Journal of Law and Economics, 21(1), 223-233.

Schaper, M., Volery, T., Weber, P., \& Lewis, K. (2011). Entrepreneurship and small business. Third Asia Pacific Edition. Queensland: John Wiley \& Sons.

Sekaran, U., \& Bougie. (2010). Research methods for business: A skill building approach. Haddington: A John Wiley and Sons, Ltd Publication.

Shinnar, R.S. \& Young, C.A. (2008). Hispanic Immigrant Entrepreneurs in the Las Vegas Metropolitan Area: Motivations for Entry into and Outcomes of Self-Employment. Journal of Small Business Management, 46(2), 242-262.

Sirmon, D.G., \& Hitt, M.A. (2003). Managing resources: linking unique resources, management, and wealth creation in family firms. Entrepreneurship Theory and Practice, 27(4), 339-358.

Tuunanen, M., \& Hyrsky, K. (2001). Entrepreneurial paradoxes in business format franchising: An empirical survey of finnish franchisees. International Small Business Journal, 19(4), 47-62.

Wang, C., Walker, E.A., \& Redmond, J. (2006). Ownership motivation and strategic planning in small business. Journal of Asia Entrepreneurship and sustainability, 2(4), 50.

Welsh, D.H.B., \& Raven, P.V. (2011). Hope among franchise leaders: Why hope has practical relevance to franchisingan exploratory study. Canadian Journal of Administrative Sciences, 28(2), 134-142.

Zellweger, T. (2007). Time horizon, costs of equity capital, and generic investment strategies of firms. Family Business Review, 20(1), 1-15. 